\title{
Zagrożenia ekologiczne społeczności lokalnych. Straty w województwie pomorskim, po nawałnicy z dnia 11/12 sierpnia 2017 r.
}

\author{
Czesław Wodzikowski \\ Wydział Nauk o Polityce i Administracji, Uniwersytet Kazimierza Wielkiego w Bydgoszczy \\ ul. ks. J. Poniatowskiego 12, 85-671 Bydgoszcz \\ c.wodz@ukw.edu.pl• ORCID 0000-0003-2759-0920
}

\begin{abstract}
Streszczenie
W artykule przedstawiono skutki nawałnicy z dnia 11/12 sierpnia 2017 roku w kontekście zagrożeń ekologicznych społeczności lokalnych na obszarze dotkniętym nawałnicą w województwie pomorskim. Zaprezentowano szacunkową wycenę strat materialnych z podziałem na: straty w lasach, w infrastrukturze sieciowej, rolnictwie, budynkach mieszkalnych, mieniu publicznym i przedsiębiorstwach. Dane o stratach zostały opublikowane przez Pomorski Urząd Marszałkowski w 2017 r. w dokumencie Raport w sprawie szacunków strat bezpośrednich po nawałnicy w dniach 11-12 sierpnia 2017 roku w województwie pomorskim.

Autor odnosi się również do zagadnienia usług ekosystemów i odporności środowiska w aspekcie bezpieczeństwa ekologicznego, którego celem jest zachowanie równowagi środowiska przyrodniczego oraz jego struktur i procesów niezbędnych do przetrwania i sprawnego funkcjonowania człowieka (Michałowski 2015: 14), oraz do kwestii zrównoważonego rozwoju w kontekście jakości życia lokalnych społeczności. Przyjęto hipotezę, że bezpieczeństwo ekologiczne w skali lokalnej jest uzależnione od stanu głównych typów ekosystemów występujących na analizowanym obszarze, w tym przypadku lasów, a szczególnie od usług generowanych przez te ekosystemy, co bezpośrednio przekładać się będzie na jakość życia lokalnych społeczności.
\end{abstract}

\section{Słowa kluczowe}

nawałnica, straty po nawałnicy, społeczność lokalna, bezpieczeństwo ekologiczne, usługi ekosystemowe

\section{Wprowadzenie}

Artykuł ukazuje skutki naturalnych zagrożeń ekologicznych (w tym przypadku burzy wiatrowej) dla regionalnych i lokalnych społeczności. W związku z tym, że głównym typem ekosystemów występujących na obszarze dotkniętym nawałnicą były ekosystemy leśne, przyjęto hipotezę, że lokalne bezpieczeństwo ekologiczne tych obszarów zależeć będzie od ich stanu, a szczególnie od możliwości generowania przez nie usług ekosystemowych.

Ekosystemy spełniają trzy podstawowe grupy funkcji:

1. funkcje, które służą rozwojowi i poprawnemu działaniu danego ekosystemu. Zaliczyć do nich można np.: zdolność samoorganizacji, stabilność oraz odporność ekosystemu; 
2. funkcje niezbędne dla poprawnego funkcjonowania innych ekosystemów oraz funkcje krajobrazowe, które wpływają np. na ogólną integralność sąsiednich ekosystemów oraz krajobraz;

3. funkcje, które są ważne dla społeczeństwa ludzkiego, a które ekosystemy generują w sytuacji poprawnego ich funkcjonowania. Funkcje te - nazywane usługami ekosystemów polegają na dostarczaniu dóbr materialnych wykorzystywanych bezpośrednio przez człowieka oraz funkcje podtrzymujące życie i podnoszące jego jakość, jak np. funkcje oczyszczające, klimatotwórcze, regulujące gospodarkę wodną, walory estetyczne, dobra kulturowe oraz naukowe (Solon 2008: 25-26).

Funkcje, jakie pełnią ekosystemy, mają więc duże znaczenie szczególnie dla lokalnych społeczności, gdyż wpływają zazwyczaj w sposób bezpośredni na ludzkie zdrowie oraz dobrobyt materialny. Stanowią tym samym podstawę właściwej jakości życia lokalnych społeczności, do której to kategorii odnoszą się zarówno cele zrównoważonego rozwoju, jak i bezpieczeństwa ekologicznego. W związku z tym właściwy stan ekosystemów, umożliwiający im generowanie usług w sposób niezakłócony, będzie warunkował w zasadniczy sposób jakość życia lokalnych społeczności, często uzależnionych od dominujących ekosystemów na obszarach ich funkcjonowania (rys. 1).

Do usług ekosystemowych zaliczyć można (Hawelke, Graczyk 2016: 34):

1. usługi regulacyjne - regulacja: klimatu, zjawisk ekstremalnych, biologiczna, procesów glebowych, zanieczyszczeń i samooczyszczania. Najważniejsze zadania usług regulacyjnych z punktu widzenia lokalnych społeczności to: regulacja temperatury i opadów, retencja, regulacja zjawisk ekstremalnych, osłabianie huraganów i sztormów, przeciwdziałanie powodziom, regulacja pożarów, przeciwdziałanie erozji, zapylanie i roznoszenie nasion, tworzenie gleby oraz pochłanianie zanieczyszczeń pyłowych;

2. usługi zaopatrzeniowe (produkcyjne) - produkcja żywności, surowce pochodzenia organicznego, zasoby biologiczne oraz zaopatrzenie w wodę. Najważniejsze zadania usług zaopatrzeniowych z punktu widzenia społeczności lokalnych to: możliwość prowadzenia upraw roślinnych i hodowli zwierząt oraz pozyskiwanie żywności (łowiectwo, zbieractwo), pozyskiwanie drewna i innych surowców drzewnych;

3. usługi wspomagające - krążenie pierwiastków, produkcja pierwotna, funkcja siedliskowa oraz cykl hydrologiczny. Najważniejsze dla lokalnych społeczności będą tu kwestie siedliskowe oraz związane z cyklem hydrologicznym;

4. usługi kulturowe - rekreacyjne, estetyczne, kulturowe, duchowe, naukowe i edukacyjne. W zakresie usług kulturowych dla lokalnych społeczności najważniejsze są funkcje w zakresie usług związanych z funkcjami rekreacyjnymi, estetycznymi i kulturowymi.

\section{Obszar badań}

Obszarem badawczym jest obszar województwa pomorskiego dotknięty skutkami nawałnicy z dnia 11/12 sierpnia 2017 r. z perspektywy bezpieczeństwa ekologicznego tego obszaru. W dniach 11-12 sierpnia 2017 r. nad Polską przeszły gwałtowne burze, którym towarzyszyły huraganowe wiatry. W ich wyniku śmierć poniosło pięć osób, a kilkadziesiąt zostało rannych. Największe straty materialne zanotowano w lasach, które miejscami zostały zniszczone całkowicie, oraz w infrastrukturze sieciowej, gdzie uszkodzeniu uległy głównie napowietrzne linie energetyczne oraz drogi. Zniszczonych zostało również wiele budynków mieszkalnych i gospodarczych. W rejonach, gdzie doszło do zaburzenia biegu rzek przez połamane 


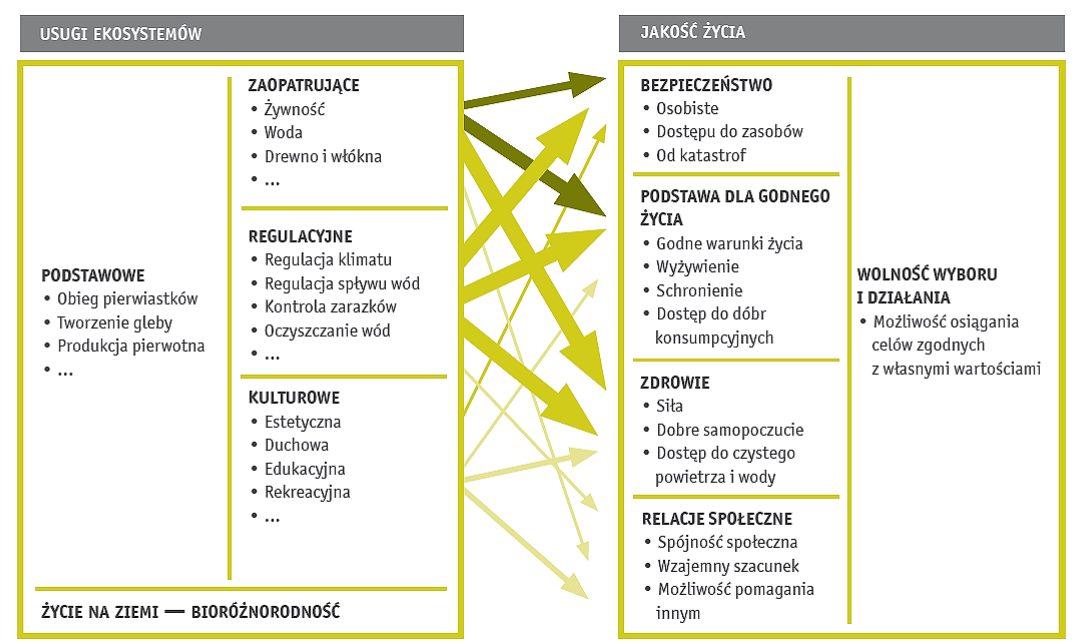

Rys. 1. Wpływ usług ekosystemowych na jakość życia człowieka (Kronenberg 2015: 5)

drzewa, nastąpiły lokalne podtopienia. Zanotowano również straty w uprawach rolnych oraz infrastrukturze turystycznej.

Województwo pomorskie (oprócz kujawsko-pomorskiego i wielkopolskiego) najbardziej odczuło skutki nawałnicy. Straty odnotowano w 31 gminach leżących w 10 powiatach województwa pomorskiego. Największe zniszczenia zanotowano w powiecie bytowskim (gminy Parchowo i Studzienice), chojnickim (gminy: Brusy, Chojnice i Czersk), kartuskim (gminy Sierakowice i Sulęczyno) oraz kościerskim (gminy: Dziemiany, Lipusz i Karsin). Poważne straty dotknęły również 11 nadleśnictw PGL Lasy Państwowe oraz lasów prywatnych w 8 powiatach.

Obszar dotknięty skutkami nawałnicy zajmuje 5,9 tys. $\mathrm{km}^{2}$ (32,1\% powierzchni województwa). Położony jest w urozmaiconej, pojezierno-równinnej części województwa (Pojezierza Bytowskie i Kaszubskie, Równina Charzykowska, Bory Tucholskie). Powierzchnia lasów na tym obszarze wynosiła 244,3 tys. ha $(36,6 \%$ areału lasów w regionie), przy czym lesistość w 11 z 31 poszkodowanych gmin wynosiła minimum $50 \%$. Na skutek nawałnicy ucierpiało 41,9 tys. ha lasów (17,2\% powierzchni lasów). Na analizowanym obszarze znajdowało się 65,1 tys. budynków mieszkalnych (22\% zasobów w regionie). Nawałnica spowodowała uszkodzenia w 2,3 tys. z nich (tj. 3,6\% budynków na tym terenie). W powiatach dotkniętych skutkami nawałnicy było 3,5 tys. km dróg powiatowych (ok. 61\% długości dróg powiatowych w regionie) i 9,o tys. km dróg gminnych (ok. 63\% długości dróg gminnych w województwie). Uszkodzeniu uległo odpowiednio ok. $3 \%$ i $5 \%$ tych dróg.

\section{Szacunkowe straty w województwie pomorskim}

Wielkość strat bezpośrednich związanych z nawałnicą szacuje się na 2,66 mld zł. Przedstawia je tabela 1 . W tabeli 2 przedstawiono wybrane rodzaje strat.

\subsection{Straty w lasach}

Wielkość strat została oszacowana na podstawie informacji PGL Lasy Państwowe, Ministerstwa Środowiska, GUS, Parku Narodowego Bory Tucholskie (PNBT) oraz gmin i powiatów. Uwzględniono straty w lasach państwowych $\left(6,6 \mathrm{mln} \mathrm{m}^{3}\right.$ drewna; 28,8 tys. ha lasów do odtworzenia) i prywatnych (997 tys. $\mathrm{m}^{3}$ drewna, 13,1 tys. ha szkód, w tym 5,2 tys. ha lasów do odtworzenia). Szacunki uwzględniają cztery elementy:

1. koszt sprzątania i odnowienia lasów (zalesienia),

2. straty gospodarcze w drewnie, 
Tabela 1. Wielkość strat bezpośrednich (Źródło: Raport w sprawie 2017).

\begin{tabular}{lc}
\hline \multicolumn{1}{c}{ Rodzaj strat } & Koszt [tys. zł] \\
\hline Lasy & 2373690 \\
Infrastruktura sieciowa & 131680 \\
Rolnictwo & 83590 \\
Budynki mieszkalne & 48820 \\
Mienie publiczne & 7710 \\
Przedsiębiorstwa & 970 \\
Akcja ratunkowa & 13200 \\
Razem & 2659660 \\
\hline
\end{tabular}

Tabela 2. Wybrany Rodzaj strat (Źródło: Raport w sprawie 2017)

\begin{tabular}{|c|c|c|}
\hline & Rodzaj strat & Koszt [tys. zł] \\
\hline \multirow{5}{*}{ Straty w lasach } & Sprzątanie i odnowienie lasów & 935580 \\
\hline & Gospodarcze (drewno) & 1418930 \\
\hline & Gospodarcze (runo leśne) & 14980 \\
\hline & Usługi ekosystemowe PN „BT" & 4200 \\
\hline & Razem: & 2373690 \\
\hline \multirow{4}{*}{$\begin{array}{l}\text { Wielkość strat bezpośrednich } \\
\text { w infrastrukturze sieciowej }\end{array}$} & Drogi & 80070 \\
\hline & Melioracje i gospodarka wodna & 3420 \\
\hline & Energetyka & 48190 \\
\hline & Razem & 131680 \\
\hline \multirow{4}{*}{$\begin{array}{l}\text { Wielkość strat bezpośrednich } \\
\text { w rolnictwie }\end{array}$} & Użytki rolne & 33750 \\
\hline & Budynki gospodarcze & 48360 \\
\hline & Maszyny & 1480 \\
\hline & Razem & 83590 \\
\hline \multirow{5}{*}{ Koszty akcji ratowniczej } & Interwencje PSP & 1900 \\
\hline & Interwencje OSP & 2480 \\
\hline & $\begin{array}{l}\text { Koszty inne, w tym: roboty publiczne, } \\
\text { społeczne, tymczasowe zakwaterowanie }\end{array}$ & 6320 \\
\hline & Usuwanie i utylizacja azbestu & 2500 \\
\hline & Razem & 13200 \\
\hline
\end{tabular}

3. straty w gospodarczym wykorzystaniu runa leśnego oraz

4. wycenę usług ekosystemowych lasów położonych w granicach PNBT z uwagi na walory przyrodnicze.

W efekcie nawałnicy ok. 43\% powierzchni lasów państwowych w regionie zostało objętych zakazem wstępu, co znacząco ograniczyło możliwość pozyskania runa leśnego, prowadząc do utraty dochodów z jego sprzedaży. Według GUS, w 2015 r. roczne przychody ze sprzedaży runa leśnego w województwie pomorskim wyniosły 34,5 $\mathrm{mln}$ zł.
Usługi ekosystemowe (w tym gospodarcze) w PNBT (4,2 mln zł):

- bazując na wskazówkach FAO, przyjęto, że wartość nieprodukcyjnych usług ekosystemowych (retencja wody, regulacja klimatu itd.) w stosunku do wartości produkcyjnych lasów jest jak 1:2;

- $\quad$ straty w PNBT określono na ok. 15 tys. $\mathrm{m}^{3}$ drewna $\left(200 \mathrm{~m}^{3}\right.$ drewna $\mathrm{z} 1$ ha lasu);

- uwzględniając ww. średnią cenę drewna $\left(186,75 \mathrm{zł} / \mathrm{m}^{3}\right)$, określono 
wartość strat gospodarczych w PNBT $(2,8 \mathrm{mln}$ zł) oraz wartość pozostałych usług ekosystemowych $(1,4 \mathrm{mln}$ zł). Wycena wszystkich usług ekosystemowych PNBT stanowi sumę obu wartości.

\subsection{Straty w infrastrukturze sieciowej}

W tej kategorii uwzględniono uszkodzone drogi (414 km gminnych, $94 \mathrm{~km}$ powiatowych i 96 km wojewódzkich), w tym mosty i przepusty, a także melioracje, infrastrukturę wodną i energetyczną. Większość informacji uzyskano bezpośrednio z poszkodowanych gmin i od gestorów poszczególnych elementów infrastruktury.

\subsection{Straty w budynkach mieszkalnych}

Przy szacowaniu strat w tej kategorii oparto się na danych udostępnionych przez poszkodowane gminy. Liczbę poszkodowanych budynków mieszkalnych (zniszczenia częściowe i całościowe) okrelono na ok. 2 350, przyjmując średnią wartość strat na poziomie 20,8 tys. zł/budynek, co dało łączoną wartość strat na poziomie $48,8 \mathrm{mln} \mathrm{zł}$.

\subsection{Straty w mieniu publicznym}

W skład mienia publicznego zaliczono m.in. placówki oświatowo-wychowawcze, szpitale i placówki służby zdrowia, domy opieki społecznej, obiekty sportowe, placówki kultury, cmentarze i inne obiekty komunalne.

Informacje pochodzą od poszkodowanych gmin i jednostek organizacyjnych samorządu województwa (instytucje kultury, parki krajobrazowe). Liczbę poszkodowanych obiektów w gminach oszacowano na 110. Przyjmując średnie straty na poziomie 48,4 tys. zł/obiekt, otrzymano kwotę $5,3 \mathrm{mln}$ zł. Kwotę tę powiększono o straty w mieniu samorządu województwa, co dało łączoną wartość strat na poziomie 7,7 mln zł.

\subsection{Straty w przedsiębiorstwach}

Posiadane informacje pochodzą od dwóch poszkodowanych przedsiębiorstw (ośrodki wypoczynkowe) oraz z miasta Chojnice (trzy przedsiębiorstwa). Oszacowane w ten sposób straty wyniosły 970 tys. zł.

Specyfiką znacznej części obszaru jest wyznaczony na nim Swiatowy Rezerwat Biosfery Bory Tucholskie. Obejmuje on prawie 3,2 tys. $\mathrm{km}^{2}$ na terenie 22 gmin województwa kujawsko-pomorskiego i pomorskiego. Podstawowym wyzwaniem rozwojowym dla tego rezerwatu jest wykorzystanie jego wysokich walorów przyrodniczo-krajobrazowych i kulturowych do wzmocnienia bazy ekonomicznej w oparciu o turystykę aktywną i pobytową, a także zrównoważoną gospodarkę leśną i rybactwo - poprzez uporządkowanie zagospodarowania rekreacyjno-turystycznego i ograniczenie emisji zanieczyszczeń do środowiska. Sprostanie temu wyzwaniu po nawałnicy będzie wyjątkowo trudne.

\section{Zakończenie}

Skutki nawałnicy wywołały największą, od co najmniej 100 lat, na tych terenach klęskę. Szacuje się, że powrót do stanu sprzed kataklizmu zajmie ponad 25 lat. Samo uprzątnięcie obszarów leśnych ma potrwać co najmniej pięć lat. Wstępne szacunki strat bezpośrednich wywołanych nawałnicą wynoszą w województwie pomorskim prawie 2,7 mld zł, co odpowiada blisko 2,6\% PKB regionu, a także przekracza 300\% średniorocznych łącznych wydatków województwa.

Największe straty żywioł spowodował w zasobach przyrodniczych. Dotyczy to przede wszystkim największego kompleksu leśnego w Polsce, jakim są Bory Tucholskie. Zniszczenia zanotowano między innymi w: Parku Narodowym „Bory Tucholskie”, Tucholskim Parku Krajobrazowym, Wdzydzkim Parku Krajobrazowym, Zaborskim Parku Krajobrazowym, na obszarach ptasich Natura 2000 (Bory Tucholskie), obszarach siedliskowych Natura 2000 (Jeziora Wdzydzkie, Sandr Brdy, Młosino-Lubnia), obszarach chronionego krajobrazu (Chojnicko-Tucholskiego, fragment Borów Tucholskich, Gowidlińskiego, Lipuskiego) oraz wielu rezerwatów przyrody. Poważne straty odnotowano w infrastrukturze drogowej, 
energetycznej, melioracyjnej oraz w rolnictwie. Zniszczone zostały budynki mieszkalne, ośrodki turystyczne i obiekty kulturalne.

Oprócz strat bezpośrednich na obszarze dotkniętym nawałnicą niewątpliwie wystąpi szereg negatywnych konsekwencji (kosztów) pośrednich. Ich oddziaływanie na rozwój lokalnych społeczności może być w okresie 5-10 lat dużo bardziej dotkliwe, niż same bezpośrednie koszty kataklizmu. Mam tu na myśli możliwość wystąpienia strat w turystyce, przetwórstwie owoców, a także w szeroko pojętym przemyśle drzewnym. Są to ważne sfery aktywności gospodarczej na tym obszarze. Można spodziewać się znaczącej redukcji liczby turystów odwiedzających ten obszar, m.in. na skutek zniszczenia infrastruktury turystycznej i zamknięcia niektórych atrakcji. Bardzo wyraźnie zmniejszy się aktywność mieszkańców i przedsiębiorstw w sektorze zbierania i przetwórstwa runa leśnego, co spowodowane będzie wprowadzonymi przez nadleśnictwa zakazami wstępu na obszary leśne. Ponadto zakłady przetwórstwa drewna (tartaki, firmy meblarskie), które korzystają z lokalnych zasobów, będą miały dużo trudniejszy dostęp do surowca gwarantującego ciągłość pracy. W efekcie należy liczyć się z nasilonymi problemami na rynku pracy, a także z obniżeniem dochodów mieszkańców i firm. Przykładowo może wzrosnąć skala upadłości lub likwidacji przedsiębiorstw. Nie bez znaczenia jest także fakt, że zniszczenia wywołane nawałnicą spowodują znaczne uszczuplenie dochodów podatkowych gmin z tytułu podatku leśnego, a także podatku od nieruchomości, czy też od prowadzonej działalności gospodarczej. To z kolei ograniczy możliwości inwestycyjne sektora publicznego na obszarze dotkniętym kataklizmem.

Wszystkie te negatywne dla rozwoju gospodarczego regionów dotkniętych skutkami nawałnicy czynniki mogą w efekcie spowodować znaczące obniżenie jakości życia społeczności lokalnych. Potwierdza to przyjętą we wstępie hipotezę, że bezpieczeństwo ekologiczne w skali lokalnej jest uzależnione od stanu głównych typów ekosystemów występujących na analizowanym obszarze, w tym przypadku lasów, a szczególnie od usług generowanych przez te ekosystemy.

Nie bez znaczenia są również straty w ekosystemach objętych formami ochrony przyrody. Ze względu na to, że poziom rozwoju społeczno-gospodarczego jest powiązany ze stanem zasobów przyrodniczych i stanem środowiska, obszary cenne przyrodniczo stają się tzw. dobrem rzadkim, którego wartość systematycznie rośnie wraz ze wzrostem zaludnienia i rozwojem gospodarczym. Tradycyjne obszary cenne przyrodniczo oceniane były głównie w aspekcie ich wartości przyrodniczej, estetycznej i ich znaczenia dla różnych form działalności człowieka (np. rozwoju turystyki). Współcześnie coraz powszechniej dostrzegana jest także ich ekonomiczna wartość (Zawilińska 2014: 113-114).

Pełne oszacowanie strat materialnych, jakie wyrządziła nawałnica, nie jest $w$ tej chwili możliwe. Zaprezentowane dane przedstawiają wyłącznie straty bezpośrednie, dla oszacowania których przyjęto określoną metodologię. W chwili obecnej trwa usuwanie szkód (szczególnie w lasach), co generuje kolejne koszty. Szczególnie dotyczy to lokalnej infrastruktury drogowej niszczonej przez ciężki sprzęt wykorzystywany do usuwania i wywożenia zniszczonych drzew. Do końca nie wiadomo, jakie będą straty $\mathrm{w}$ turystyce (według informacji osób prowadzących usługi agroturystyczne rezerwacje zmniejszyły się o ok. 30\%) i działalności gospodarczej. Nie dokonano również pełnej wyceny strat spowodowanych utratą zdolności świadczenia usług przez zniszczone ekosystemy. Uważam, że łączne straty (bezpośrednie i pośrednie) spowodowane nawałnicą z dnia 11/12 sierpnia 2012 r. wielokrotnie przekroczą kwotę strat bezpośrednich.

\section{Bibliografia}

Hewelke E.A., Graczyk M., 2016, Ustugi ekosystemów jako instrument wspierania decyzji w gospodarce przestrzennej i ochronie środowiska, Inżynieria Ekologiczna (Ecological Engineering), vol. 49, 33-40. 
Kronenberg J., 2015, Ustugi ekosystemów w mieście i dla miasta, http://www.euroreg.uw.edu.pl, dostęp (11.04.2017).

Michałowski A., 2015, Ustugi środowiska w świetle bezpieczeństwa ekologicznego, Ekonomia i Środowisko, $\mathrm{nr} 4$ (55), 10-24.

Nowak A., 2014, Rola odporności środowiska w planowaniu przestrzennym, Problemy Ekologii Krajobrazu, t. 37, 7-14.

Rosini M., Takacs V., Baldi A. i in., 2001, Koncepcja świadczeń ekosystemowych $i$ jej znaczenie w ochronie przyrody polskiego krajobrazu rolniczego, Chrońmy Przyrodę Ojczystą, nr 67 (1) 3-2o.
Solon J., 2008, Koncepcja „Ecosystem Services” $i$ jej zastosowanie w badaniach ekologiczno-krajobrazowych, Problemy Ekologii Krajobrazu, nr 21, 25-44.

Zawilińska B., 2014, Ekonomiczna wartość obszarów chronionych. Zarys problematyki i metodyka badań, Zeszyty Naukowe Uniwersytetu Ekonomicznego w Krakowie, nr 12 (936), 113-129.

(Web-o1) Raport w sprawie szacunków strat bezpośrednich po nawatnicy w dniach 11-12 sierpnia 2017 roku w województwie pomorskim, www: pomorskie. eu/urzad-marszalkowski-wojewodztwa-pomorskiego, (dostęp 11.04.2017).

\title{
Ecological threats of local communities: Losses in the Pomeranian Voivodeship, after the storm of $11^{\text {th }} / 12^{\text {th }}$ August 2017
}

\begin{abstract}
The article presents the effects of the storm of $11^{\text {th }} / 12^{\text {th }}$ August 2017 in the context of ecological threats to local communities in the affected area in the Pomeranian Voivodeship. The estimated valuation of material losses presented in the article is divided into several categories: losses in forests, network infrastructure, agriculture, residential buildings, public property and companies.

The author also refers to the issues of ecosystem services and environmental resilience in the aspect of ecological security and of sustainable development from the perspective of the quality of life of local communities. It has been hypothesised that ecological security on a local scale depends on the condition of the main types of ecosystems occurring in the analysed area - in this case, forests, and especially services generated by these ecosystems.
\end{abstract}

\section{Keywords}

storm, losses after the storm, local community, ecological security, ecosystem services 